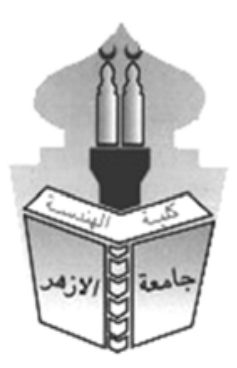

\title{
ASSESSING THE IMPACT OF SEMI-CIRCULAR BAFFLE BLOCKS ON SCOUR DOWNSTREAM SLUICE GATES
}

\section{Mamdouh Ahmed Dardeer}

Civil Eng. Department, Faculty of Engineering, Al-Azhar University, Cairo, Egypt

Received :4 Nov. $2021 \quad$ Accepted:16 Dec 2021

\section{ABSTRACT}

In the framework of expanding the arable land by constructing mega hydraulic structures that might be subjected to failure due to scour that implies the extension of the aprons, which adds extra costs. Accordingly, this research was originated with the impartial of assessing the impact of semi-circular baffle blocks on scour downstream sluice gates, in terms of length and depth. 40 experiments were carried out in Hydraulic Laboratory in AlAzhar University, where a flume equipped with measuring devices was set up. Three ratios of baffle blocks diameter to height " $\mathrm{D}_{b} / \mathrm{H}_{b}$ " and three ratios of their location from the gate to the length of the apron downstream (D.S) the gate " $\mathrm{L}_{\mathrm{b}} / \mathrm{L}_{\mathrm{f}}$ " were considered. Runs were conducted without semi-circular baffle blocks, as a reference, for comparison purposes. Measurements were undertaken; represented on graphs and analyzed. Conclusions were deduced and recommendations were suggested. The research results highlighted that implementing $\mathrm{D}_{\mathrm{b}} / \mathrm{H}_{\mathrm{b}}=0.78$, reduced scour length so as depth, at " $\mathrm{L}_{\mathrm{b}} / \mathrm{L}_{\mathrm{f}}=0.37$ ". 


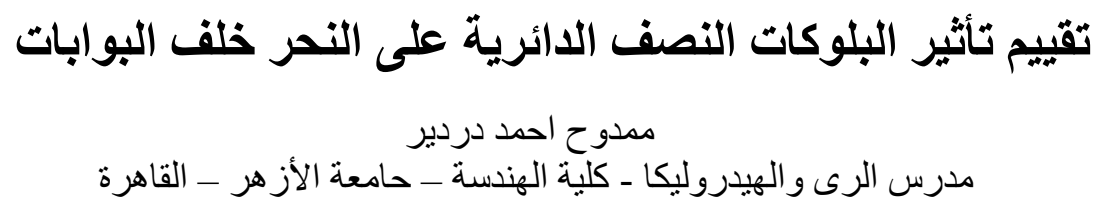

في إطار توسيع رقعة الأراضي الصالحة للزر اعة، من خلال إنشاء المنشآت الهيدروليكية الضخمة التى قد يهددها النحر وبالتالى يجب زياده طول الفرش مما يؤدى إلى زيادة التكلفة. وبالتبعية بدأ هذا البحث بهذف تقييم تأثير البلوكات النصف دائرية على النحر ، حيث تم إجر اء •ـ تجربة في معمل الهيدروليكا بجامعة الأزهر تحت نأثير تغيير نسبة "أقطار البلوكات إلى ارتفاعاتها Db / Ho ثلاث مر ات، وكذا تغيير نسبة "بعدها عن البو ابة الى طول

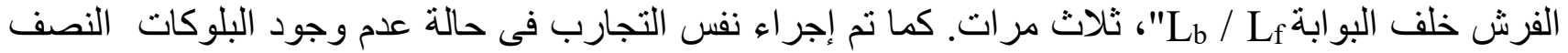
دائرية ، لتستخدم كقيم مرجعية لأغر اض المقارنة. وتم أخذ القياسات؛ وتمثيلها بيانياً وبتحليلها تم استتباط الاستنتاجات

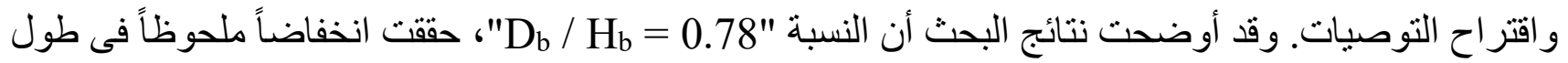

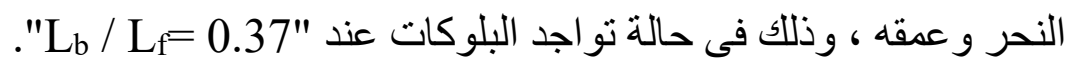

\section{INTRODUCTION}

Water structures are important structures that collapse if cracked causing unexpected disasters. Accordingly, this research was initiated with the objective of assessing the impact of semi-circular baffle blocks on scour downstream sluice gates, in terms of length and depth.

Many studies investigated the factors that affect such structures, in terms of scour at their downstream, as scour implies the extension of their aprons, which adds extra costs to the structure. Among them for example is U.S. Bureau of reclamation (10) who conducted measurements to the hydraulic jump length at Froude number 2-20. Their results flagged out that the ratio between the jump length to height is 6.9. In addition, Aboulatta, N., (2) investigated, analytically and experimentally, apron jets in radial basins for free jumps, where she designated the bed jet influence on free jump characteristics of the free hydraulic jump. Likewise, El-Masry (4) implemented single, double, and fully baffled aprons with different baffle block shapes. His results signposted that fully baffled apron proved its applicability. Similarly, El- Enany et al. (5) tested three lines of baffle blocks at different angles, where their results indicated 
that baffle block shape, dimension and arrangement affect the scour hole dimensions. Accordingly, not any solution is applicable to any condition. In contrast, Ali, M., (8) investigated the efficiency of parabolic sill downstream hydraulic structures. Likewise, Alashry, O., (9) investigated the combination of vertical so as horizontal concavities on scour. His results reflected that at $\mathrm{X}=1.67$, reasonable $\mathrm{y}_{2} / \mathrm{y}_{1}$ values were obtained. Moreover, Abdelhaleem, H., (1) studied the optimum design of staggered concrete blocks downstream regulators, where she studied the effect of flow characteristics on the end sill. Her results indicated that baffle location at 30 to $50 \%$ of basin length provided the least scour. Helmy, A., (3) investigated the impact of Y-sill on hydraulic jumps, where he studied three angles (i.e. $45^{\circ}, 30^{\circ}$ and $15^{\circ}$ ). His results indicated that angle $30^{\circ}$ at $\mathrm{L}_{\mathrm{b}} / \mathrm{L}_{\mathrm{f}}=0.22$ provided the least scour depth. Javad, F. and Hossein, Kh., (7) studied the local scour downstream of adverse stilling basins where a sub-merged wall jet issued from a sluice gate. Experiments were conducted in a wide range of Froude numbers, grain sizes, tail water depths, and stilling basin slopes The results showed that the scour profiles at any bed slope follow shape similarity. Lately, Ibrahim M. M., (6) studied the impacts of block shapes on the flow pattern downstream a radial gate. Forty-five (45) exploratory runs were done. Four different states of baffle blocks were considered, notwithstanding an instance of level floor without blocks was incorporated into the test program to evaluate the impact of utilizing the blocks. Each case was tried with various flow conditions; three unique discharges and three diverse tail water depths were utilized. Results were investigated and graphically exhibited. The tests demonstrated that the blocks exhibited a high proficiency in limiting the detached impact of the flow pattern downstream the gate.

\section{PARAMETRIC INVESTIGATION}

A non-dimensional analysis was conducted to correlate the variables contributing in the problem in hand for a single line of baffles, where their geometry are defined on figure (1) and table (1). 
Relationships were obtained between jump length $\left(\mathrm{L}_{\mathrm{j}}\right)$, Froude number $\left(\mathrm{F}_{\mathrm{r}}\right)$, relative scour depth $\left(D_{s} / D_{s w}\right)$ and scour length to depth $\left(L_{s} / L_{s w}\right)$, where the depths upstream and downstream of the jump were denoted as $Y_{1}$ and $Y_{2}$, respectively. $\Delta \mathrm{Y}$ is the height of the hydraulic jump, as follows:

$$
\Delta \mathrm{Y}=\left(\mathrm{Y}_{2}-\mathrm{Y}_{1}\right)
$$

Length of jump is denoted by $\mathrm{L}_{\mathrm{j}}$, as follows:

$\mathrm{L}_{\mathrm{j}}=6.9 \Delta \mathrm{Y}$

$\left(\mathrm{y}_{2}\right)$ is given in terms of $\left(\mathrm{y}_{1}\right)$, as follows:

$$
y_{2}=-\frac{y_{1}}{2}+\sqrt{\frac{2 v_{1}^{2} y_{1}}{g}+\frac{y_{1}^{2}}{4}}
$$

Froude number $\left(\mathrm{F}_{\mathrm{r}}\right)$ is as follows:

$$
F_{r}=\frac{v}{\sqrt{g y}}
$$

If Froude number (Fr) is introduced to equation (3), the following is obtained: $y_{2}=\frac{y_{1}}{2}\left(\sqrt{1+8 F_{r}^{2}}-1\right)$

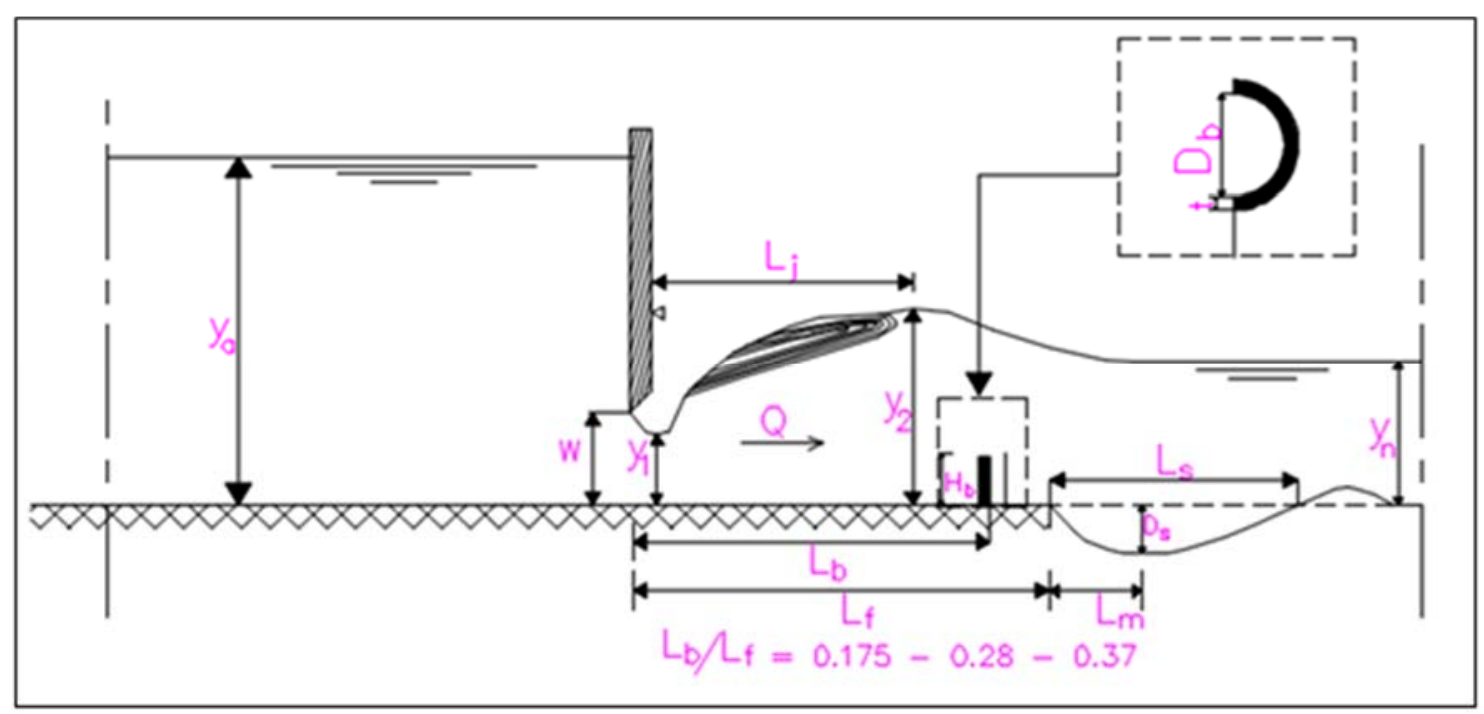




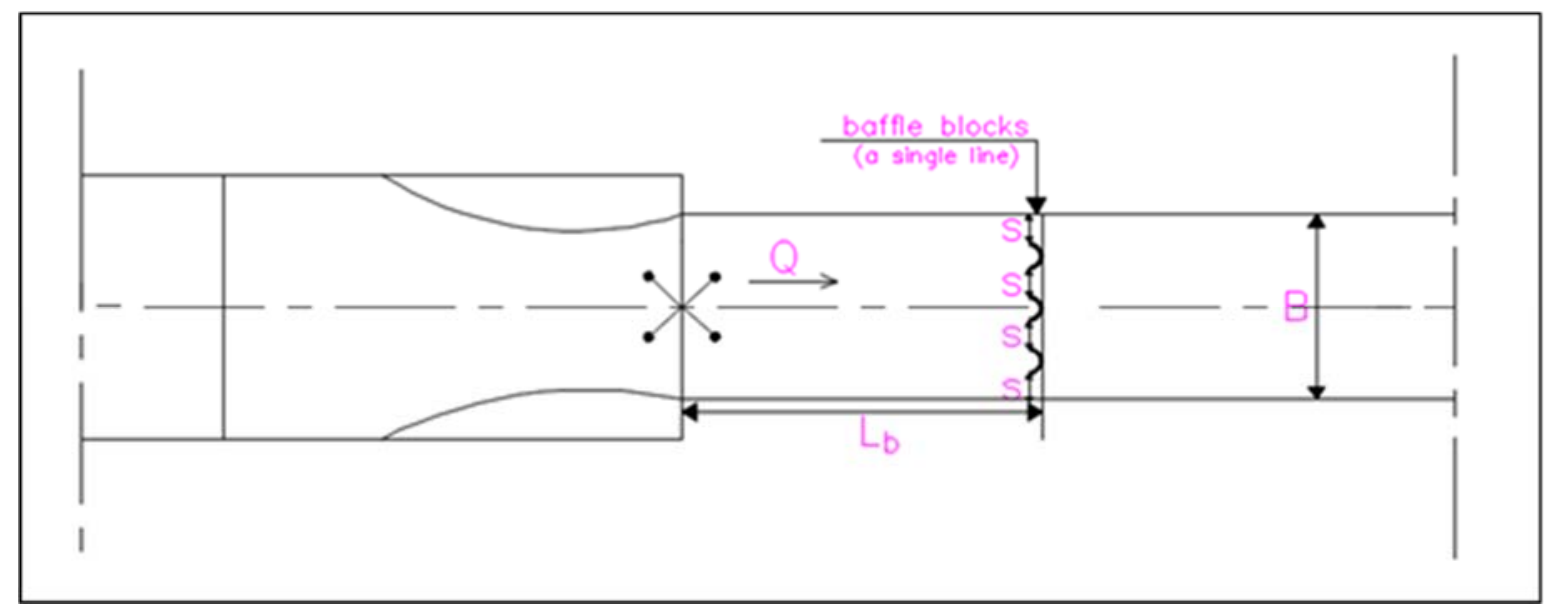

Figure (1) Geometrical parameters in elevation and plan

Table (1) Variables units and dimensions

\begin{tabular}{|c|c|c|c|}
\hline Symbol & Definition & Units & Dimension \\
\hline \multicolumn{4}{|c|}{ Geometrical properties } \\
\hline $\mathbf{L}_{\mathbf{f}}$ & Length of apron downstream the gate. & $\mathbf{m}$ & $\mathbf{L}$ \\
\hline $\mathbf{L}_{\mathbf{b}}$ & Distance from the control structure to the first sill. & $\mathbf{m}$ & $\mathbf{L}$ \\
\hline 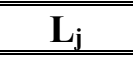 & Length of the hydraulic jump. & 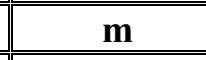 & $\overline{\mathbf{L}}$ \\
\hline $\mathbf{L}_{\mathbf{j w}}$ & Length of the hydraulic jump (case without sill). & $\mathbf{m}$ & $\mathbf{L}$ \\
\hline $\mathbf{t}$ & Thickness of sill. & 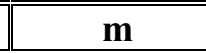 & 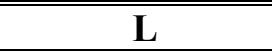 \\
\hline $\mathbf{s}$ & Distance between baffle blocks. & $\mathbf{m}$ & $\mathbf{L}$ \\
\hline $\mathbf{D}_{\mathbf{b}}$ & Diameter of the sill. & $\mathbf{m}$ & $\underline{\mathbf{L}}$ \\
\hline $\mathbf{H}_{\mathrm{b}}$ & Height of the sill. & $\overline{\mathrm{m}}$ & $\overline{\mathbf{L}}$ \\
\hline $\mathbf{B}$ & Width of channel. & $\mathbf{m}$ & $\mathbf{L}$ \\
\hline$\overline{\mathbf{W}}$ & Opening the gate. & $\overline{\mathbf{m}}$ & $\overline{\mathbf{L}}$ \\
\hline$\overline{\mathbf{y}_{1}}$ & Depth at beginning of hydraulic jump. & $\overline{\mathrm{m}}$ & $\overline{\mathbf{L}}$ \\
\hline $\mathbf{y}_{2}$ & Depth at end of hydraulic jump. & $\mathbf{m}$ & $\mathbf{L}$ \\
\hline$\overline{y_{n}}$ & Tail water depth. & $\mathbf{m}$ & $\overline{\mathbf{L}}$ \\
\hline \multicolumn{4}{|c|}{ Flow properties } \\
\hline $\mathrm{V}_{1}$ & Velocity at beginning jump. & m/sec & $\mathbf{L T}^{-1}$ \\
\hline $\mathbf{V}_{2}$ & Velocity at end jump. & $\mathrm{m} / \mathrm{sec}$ & $\mathbf{L T}^{-1}$ \\
\hline $\mathbf{Q}$ & Discharge of the channel. & $\mathrm{m}^{3} / \mathrm{sec}$ & $\mathbf{L}^{3} \mathbf{T}^{-1}$ \\
\hline$\overline{\mathrm{g}}$ & Gravitational acceleration. & $\overline{\mathrm{m} / \mathrm{sec}^{2}}$ & $\mathbf{L T}^{\mathbf{2}}$ \\
\hline \multicolumn{4}{|c|}{ Fluid properties } \\
\hline 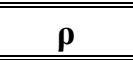 & Mass density of fluid. & $\mathrm{kgm}_{\mathbf{m}} / \mathrm{m}^{3}$ & $\mathrm{ML}^{-3}$ \\
\hline 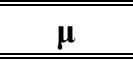 & Dynamic viscosity. & $\mathrm{kg}_{\mathrm{m} / \mathrm{m} . \mathrm{sec}}$ & $\mathbf{M L}^{-1} \mathbf{T}^{-1}$ \\
\hline \multicolumn{4}{|c|}{ Soil properties } \\
\hline S.G & Soil Specific gravity. & ------- & Dimensionless \\
\hline D50 & Mean diameter of sediments. & $\mathbf{m}$ & $\mathbf{L}$ \\
\hline Ø & Internal friction angel of soil. & ב------ & Dimensionless \\
\hline \multicolumn{4}{|c|}{ Scour properties } \\
\hline Ds & Maximum scour depth. & $\mathbf{m}$ & $\mathbf{L}$ \\
\hline 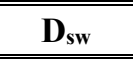 & Maximum scour depth (case without sill). & $\overline{\mathbf{m}}$ & 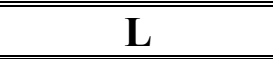 \\
\hline
\end{tabular}




\begin{tabular}{|c|c|c|c|}
\hline Ls & Length of scour hole. & $\mathbf{m}$ & $\overline{\mathbf{L}}$ \\
\hline $\mathbf{L}_{\text {sw }}$ & Length of scour hole (case without sill). & $\mathbf{m}$ & $\mathbf{L}$ \\
\hline$\overline{\mathbf{L}_{\mathbf{m}}}$ & Position of maximum scour depth. & $\mathbf{m}$ & $\overline{\mathbf{L}}$ \\
\hline
\end{tabular}

S.G could be cancelled. This provides

$\Phi=f\left(L_{f}, L_{b}, L_{j}, L_{j w}, t, H_{b}, B, D_{b}, y_{1}, y_{n}, Q, \rho, g, \mu, S . G, \varnothing, D_{s}, D_{s w}, L_{s}, L_{s w}, L_{m}, s, v_{1}, v_{2}\right)$

Where:

B : channel width

Q : discharge

$\rho:$ density of fluid

$\mathrm{g}:$ acceleration due to gravity

$\mu$ : dynamic viscosity

S.G : specific density

$\varnothing$ : selected soil diameter

The parameters $\varnothing$ and S.G could be deleted from the variables.

According to Buckingham $\pi$-theorem, the general form of relationship between these variables may be written as follows:

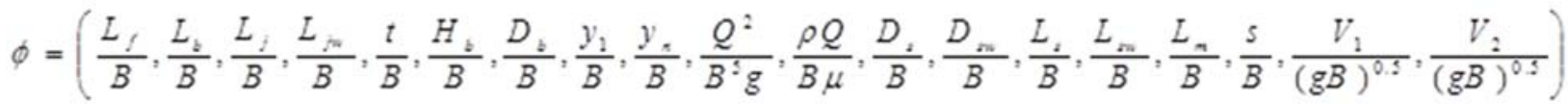

Taking the properties of $\pi$-terms into account, the following relationship was obtained:

$$
\phi_{1}=\left(\frac{L_{b}}{L_{f}}, \frac{L_{j}}{L_{j w}}, \frac{t}{s}, \frac{D_{b}}{H_{b}}, \frac{h_{1}}{h_{2}}, \frac{y_{2}}{y_{1}}, \frac{V_{1}}{V_{2}}, F_{r}, R_{n}, \frac{D_{50}}{B}, \frac{D_{s}}{D_{s w}}, \frac{L_{s}}{L_{s w}}, \frac{L_{m}}{y_{n}}\right) \ldots
$$

Where:

$\mathrm{L}_{\mathrm{b}} / \mathrm{L}_{\mathrm{f}}$ : relative apron length

$\mathrm{L}_{\mathrm{j}} / \mathrm{L}_{\mathrm{jw}}$ : relative hydraulic jump length

$\mathrm{t} / \mathrm{s}$ : ratio between baffle blocks thickness to the distance between them

$\mathrm{D}_{\mathrm{b}} / \mathrm{H}_{\mathrm{b}}$ : ratio between diameter and height of baffle block

$\mathrm{y}_{2} / \mathrm{y}_{1}:$ relative conjugate depth 
$\mathrm{v}_{1} / \mathrm{v}_{2}$ : relative conjugate velocity

$\mathrm{F}_{\mathrm{r}} \quad$ : Froude number

$\mathrm{R}_{\mathrm{n}} \quad$ : Reynolds number

$\mathrm{D}_{50} / \mathrm{B}$ : ratio between Mean diameter of sediments and width of channel

$\mathrm{D}_{\mathrm{s}} / \mathrm{D}_{\mathrm{sw}}$ : relative scour depth

$\mathrm{L}_{\mathrm{s}} / \mathrm{L}_{\mathrm{sw}}$ : relative scour length

$\mathrm{L}_{\mathrm{m}} / \mathrm{y}_{\mathrm{n}}$ is the ratio between position maximum depth and tail water depth.

Finally, the function will be as follows:

$F_{r}=\phi\left(\frac{L_{b}}{L_{f}}, \frac{L_{j}}{L_{j w}}, \frac{t}{s}, \frac{D_{b}}{H_{b}}, \frac{y_{2}}{y_{1}}, \frac{V_{1}}{V_{2}}, \frac{D_{50}}{B}, \frac{D_{s}}{D_{s w}}, \frac{L_{s}}{L_{s w}}, \frac{L_{m}}{y_{n}}\right)$

\section{EXPERIMENTAL INVESTIGATION}

Forty tests were conducted. The experimental investigation was carried out in the Hydraulic Laboratory of Al- Azhar University, where a flume was set up an equipped with measuring devices. The flume cross section is supported by $30 \times 30 \mathrm{~cm}$ rectangular steel frame with visible clear polycarbonate sides. Its length $4.0 \mathrm{~m}$, figures (2) and (3). The ratio $\mathrm{D}_{\mathrm{b}} / \mathrm{H}_{\mathrm{b}}$ of the baffle blocks was varied to be $0.62,0.78$ and 1.00 , while their width ( $\mathrm{t}$ ) was kept constant to be $0.30 \mathrm{~cm}$. Their placement location was varied 3 times $\mathrm{L}_{\mathrm{b}} / \mathrm{L}_{\mathrm{f}}$ was $0.175,0.28$ and 0.37 . In addition, 5 discharges were considered.

The baffle blocks were fitted at different locations, relative to the gate. The bed material was accurately leveled and checked by a water gauge. The hydraulic jump was formed under free flow downstream the gate and stabilized, after which the measurements were undertaken; observations were recognized and photos were captured.

The experimental procedure progressed, as follows:

- The required discharge was passed, where a measuring weir (i.e. pre-calibrated in the hydraulic laboratory, $\mathrm{Q}=0.371 \mathrm{H}^{1.5}$ ) was implemented; figure (4).

- The sequent depth $y_{2}$ was measured.

- Jump length $L_{j}$ was measured from the jump edge to the top roller of the jump. 
- The longitudinal scour whole profile was measured at intervals of $5 \mathrm{~cm}$ by means the gauge and Ultrasonic.

- The velocity distribution downstream the elements and the normal water depth were measured.

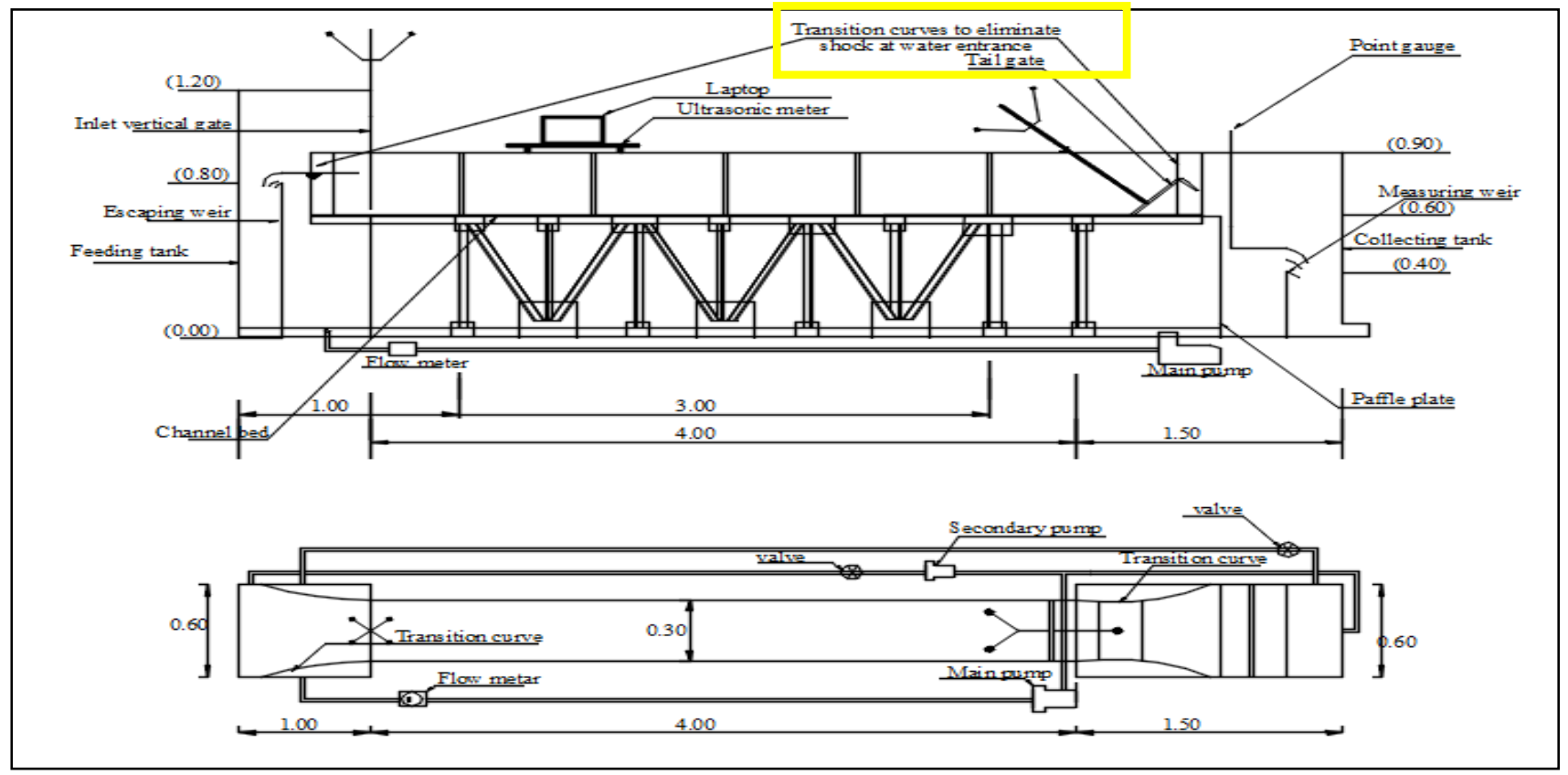

Figure (2) the experimental flume layout

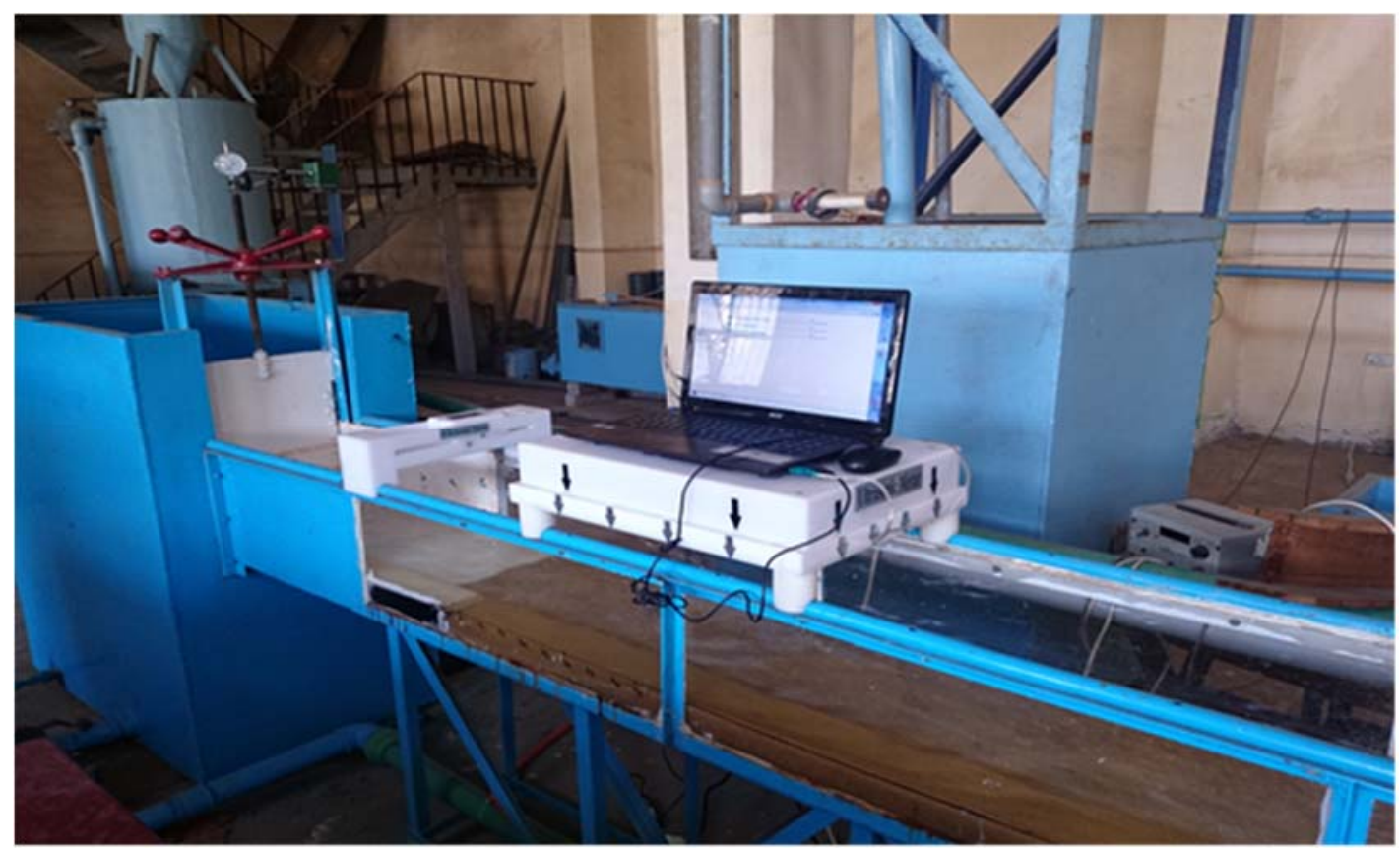

Figure (3) The experimental flume with measuring devices (Ultrasonic devices - multi spots) 


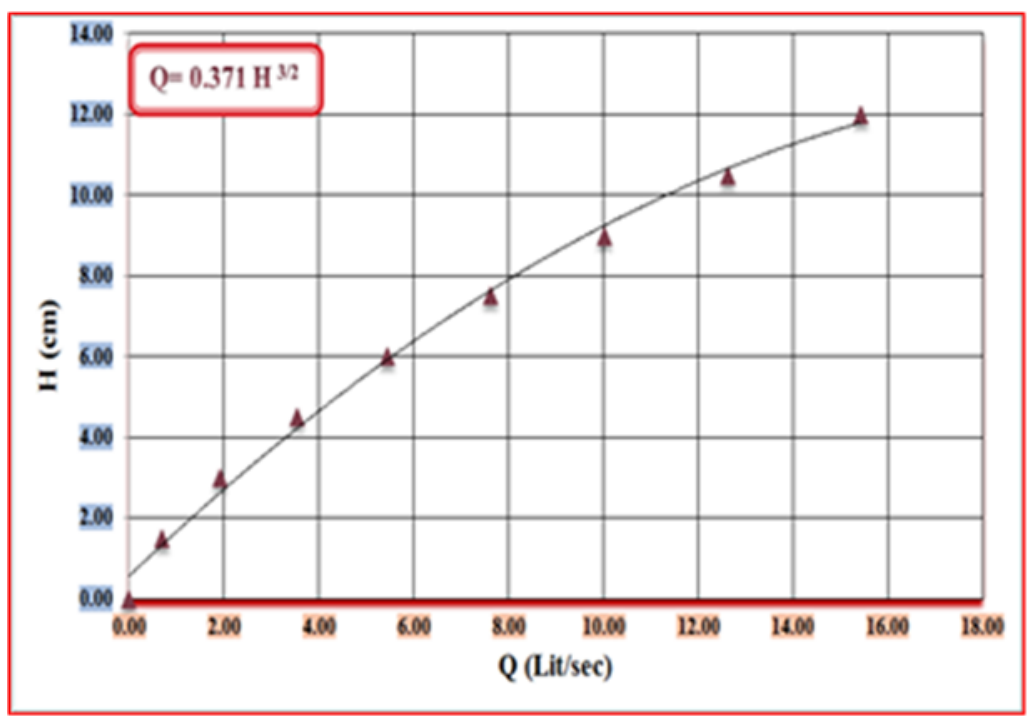

Figure (4) Weir pre-calibration

\section{RESULTS ANALYSIS AND DISCUSSION}

The measurements were analyzed, from which table (2) is provided to summarize the obtained results. In addition, self-explanatory graphs were produced and are presented on figures (5) to (13).

\section{4.a. ANALYZING AND DISCUSSING $\mathbf{L}_{\mathbf{j}} / \mathbf{L}_{\mathbf{j w}}$ RESULTS}

Figures (5), (6) and (7) related Froude number $\left(\mathrm{F}_{\mathrm{r}}\right)$ to $\mathrm{L}_{\mathrm{j}} / \mathrm{L}_{\mathrm{jw}}$, from which, the following were designated:

- $\mathrm{L}_{\mathrm{j}} / \mathrm{L}_{\mathrm{jw}}$ is directly proportional to $\mathrm{F}_{\mathrm{r}}$.

- For all Froude number $\left(\mathrm{F}_{\mathrm{r}}\right)$ values, the reasonable position for the baffle blocks was at $\mathrm{L}_{\mathrm{b}} / \mathrm{L}_{\mathrm{f}}=0.37$, where at $\left(\mathrm{D}_{\mathrm{b}} / \mathrm{H}_{\mathrm{b}}\right)$ of $1.00,0.78$ and 0.62 , the jump length was reduced 33 to $45 \%, 43$ to $55 \%$ and 17 to $28 \%$, respectively.

- This indicated that the appropriate position to the sills at $\mathrm{L}_{\mathrm{b}} / \mathrm{L}_{\mathrm{f}}=0.37$ at $\left(\mathrm{D}_{\mathrm{b}} / \mathrm{H}_{\mathrm{b}}\right)$ $=0.78$, as it reduced the jump length by $55 \%$. 


\section{4.b. ANALYZING AND DISCUSSING SCOUR LENGTH RESULTS}

Figures (8), (9) and (10) related Froude numbers $\left(\mathrm{F}_{\mathrm{r}}\right)$ to $\mathrm{L}_{\mathrm{s}} / \mathrm{L}_{\mathrm{sw}}$, from which the following were highlighted:

- $\mathrm{L}_{\mathrm{s}} / \mathrm{L}_{\mathrm{sw}}$ is directly proportion to Froude number $\left(\mathrm{F}_{\mathrm{r}}\right)$.

- The appropriate sill position is at $\mathrm{L}_{\mathrm{b}} / \mathrm{L}_{\mathrm{f}}=0.37$, where at $\left(\mathrm{D}_{\mathrm{b}} / \mathrm{H}_{\mathrm{b}}\right)$ of $1.00,0.78$ and 0.62 , the scour length was reduced by 28 to $38 \%, 31$ to $45 \%$ and 25 to $28 \%$, respectively.

- This indicated that the appropriate position to the sill is at $\mathrm{L}_{\mathrm{b}} / \mathrm{L}_{\mathrm{f}}=0.37$ at $\left(\mathrm{D}_{\mathrm{b}} / \mathrm{H}_{\mathrm{b}}\right)$ $=0.78$, as it reduced the scour length by $45 \%$.

\section{4.c. ANALYZING AND DISCUSSING SCOUR DEPTH RESULTS}

Figures (11), (12) and (13) were related Froude number $\left(\mathrm{F}_{\mathrm{r}}\right)$ to $\mathrm{L}_{\mathrm{s}} / \mathrm{L}_{\mathrm{sw}}$, from which the following were highlighted:

- $\mathrm{D}_{\mathrm{s}} / \mathrm{D}_{\mathrm{sw}}$ is directly proportion to Froude number $\left(\mathrm{F}_{\mathrm{r}}\right)$

- The appropriate sill position is at $\mathrm{L}_{\mathrm{b}} / \mathrm{L}_{\mathrm{f}}=0.37$, where at $\left(\mathrm{D}_{\mathrm{b}} / \mathrm{H}_{\mathrm{b}}\right)$ of $1.00,0.78$ and 0.62 , the scour depth was reduced by 30 to $36 \%, 38$ to $42 \%$ and 14 to $26 \%$, respectively.

- This indicated that the appropriate position to the sill is at $\mathrm{L}_{\mathrm{b}} / \mathrm{L}_{\mathrm{f}}=0.37$ at $\left(\mathrm{D}_{\mathrm{b}} / \mathrm{H}_{\mathrm{b}}\right)$ $=0.78$, as it reduced the scour depth by $42 \%$.

Table (2) Semi-circular baffle block results

\begin{tabular}{|c||c||c|c|}
\hline $\begin{array}{c}\text { Relative } \\
\left(\mathbf{D}_{\mathbf{b}} / \mathbf{H}_{\mathbf{b}}\right)\end{array}$ & $\begin{array}{c}\text { Length of jump at } \\
\mathbf{L}_{\mathbf{b}} / \mathbf{L}_{\mathbf{f}}=\mathbf{0 . 3 7}\end{array}$ & $\begin{array}{c}\text { Scour length } \\
\text { at } \mathbf{L}_{\mathbf{b}} / \mathbf{L}_{\mathbf{f}}=\mathbf{0 . 3 7}\end{array}$ & $\begin{array}{c}\text { Scour depth } \\
\mathbf{L}_{\mathbf{b}} / \mathbf{L}_{\mathbf{f}}=\mathbf{0 . 3 7}\end{array}$ \\
\hline \hline 1.00 & $33-45 \%$ & $28-38 \%$ & $30-36 \%$ \\
\hline 0.78 & $43-55 \%$ & $31-45 \%$ & $38-42 \%$ \\
\hline 0.62 & $17-28 \%$ & $25-28 \%$ & $17-25 \%$ \\
\hline Min/max & $17 \%-55 \%$ & $25 \%-51 \%$ & $14 \%-26 \%$ \\
\hline
\end{tabular}




\section{CONCLUSIONS AND RECOMMENDATIONS}

Based on the above, the following are the deduced conclusions:

- Semi-circular baffle blocks form possesses a reasonable energy dissipation.

- Semi-circular baffle blocks afforded a reasonable reduction in scour length and depth so as jump height.

- The ratio $\left(\mathrm{D}_{\mathrm{b}} / \mathrm{H}_{\mathrm{b}}\right)=0.78$ at $\mathrm{L}_{\mathrm{b}} / \mathrm{L}_{\mathrm{f}} 0.37$ provided reasonable results.

Based on the above, the following recommendations were suggested:

- Double line of semi-circular baffle blocks is to be investigated.

- Wider ranges of diameters so as Froude number and discharge are to be investigated.

\section{REFERENCES}

1. Abdelhaleem, H. "Optimum desigen of staggered concrete blocks downstream of regulators" Unpublished M.Sc. Thesis, Al-Azhar University, Cairo, Egypt, 2010.

2. Aboulatta, N. "Radial Free Jump Controlled by Jets Downstream Low Head Hydraulic Structures". Bulletin of the Faculty of Engineering, Ain Shams University, Vol. 29, No 1, March 1994, pp.79-95.

3. Helmy, A, "Efficiency of Using Unconventional Asymmetrical Sills Dissipaters Down Stream Hydraulic Structures" Unpublished M.Sc Thesis, Al-Azhar University, Cairo, Egypt, 2014.

4. El-Masry, A. A.,: "Influence of A Fully Angle Baffled Apron On Scour Behind A Hydraulic Structure” Mansoura Engeineering Journal Vol. 26, No. 4 Mansoura, Egypt, 2001.

5. El-Anany M. A., Elmasry A. A., Sobeih M. F., and Ussry E.,: "Minimizing Scour Downstream Control Structures Using Semi-Circular Baffle Blocks". Civil Engineering Research Magazine, Vol. 25 No. 3 October 2003, pp. 1437-54. 
6. Ibrahim M. M,: "Improve the Efficiency of Stilling Basin Using Different Types of Blocks". American Journal of Engineering Research (AJER) Volume-6, Issue8, 2017.

7. Javad, F., and Hossein, Kh., : "Investigation on local scour downstreamof adverse stilling basins". Ain Shams Engineering Journal Vol. 5, No. 2 Ain Shames, Egypt, 2014.

8. Ali, M.,: "Using Aprons Of Formed Surfaces As Energy Dissipaters Down Stream Hydraulic Structures". Ph.D. Thesis. Al-Azhar University, Faculty Of Engineering, Cairo, Egypt. 2008.

9. Alashry, O.,: "Control of hydraulic jump by curved sill" M.Sc. Thesis. Al-Azhar University, Faculty Of Engineering, Cairo, Egypt. 2008.

10. U.S. Bureau of reclamation, Progress report II, Research study on stilling basins, energy dissipator, and associted appurtenances, Hydr. Lab Rep. Hyd-399, June, 1955. 
ASSESSING THE IMPACT OF SEMI-CIRCULAR BAFFLE BLOCKS ON SCOUR DOWNSTREAM SLUICE GATES

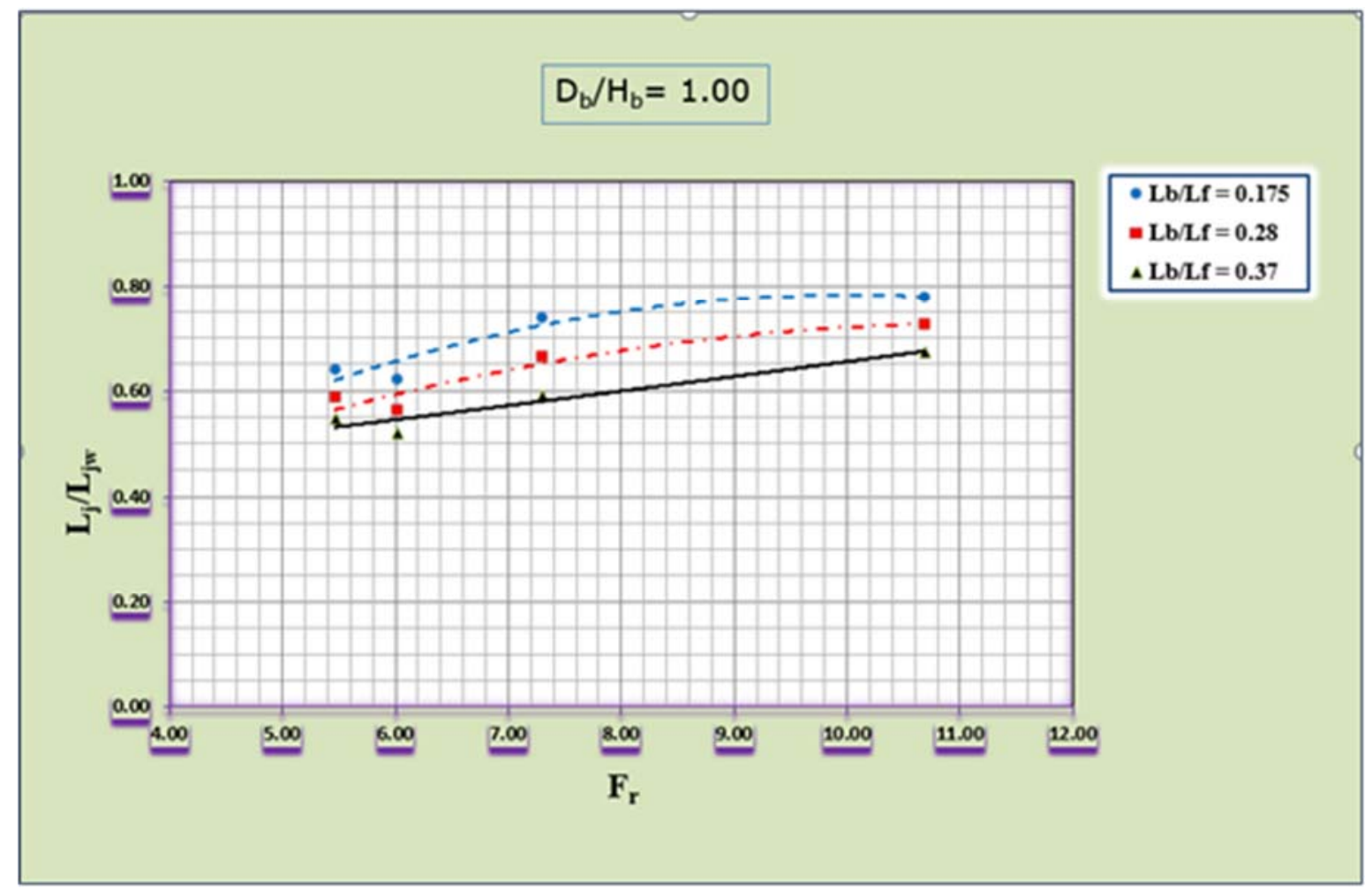

Figure (5) Relation between $\left(\mathrm{F}_{\mathrm{r}}\right)$ and $\mathrm{L}_{\mathrm{j}} / \mathrm{L}_{\mathrm{jw}}$ for $\mathrm{D}_{\mathrm{b}} / \mathrm{H}_{\mathrm{b}}=1.00$

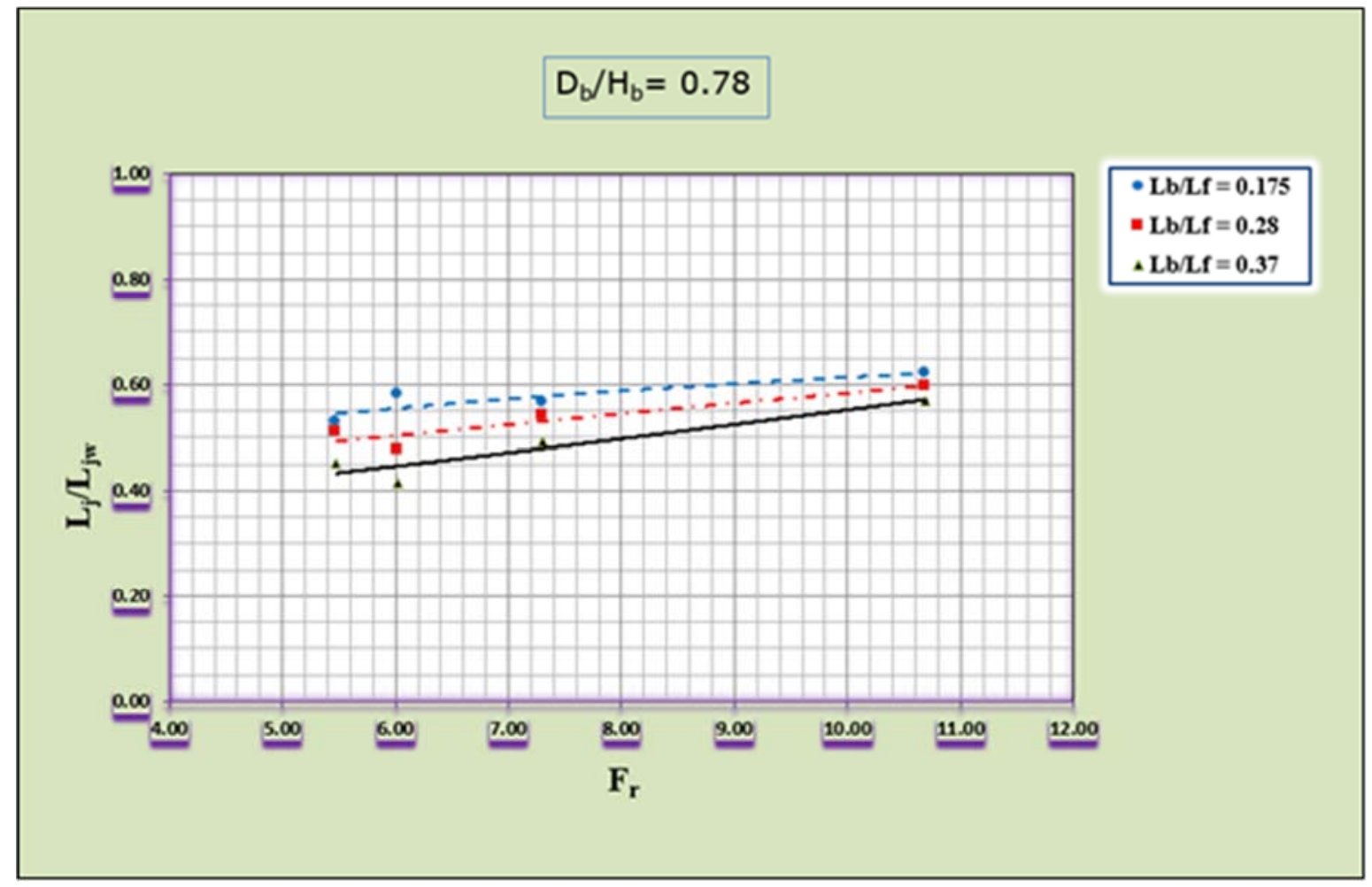

Figure (6) Relation between $\left(\mathrm{F}_{\mathrm{r}}\right)$ and $\mathrm{L}_{\mathrm{j}} / \mathrm{L}_{\mathrm{jw}}$ for $\mathrm{D}_{\mathrm{b}} / \mathrm{H}_{\mathrm{b}}=0.78$ 
ASSESSING THE IMPACT OF SEMI-CIRCULAR BAFFLE BLOCKS ON SCOUR DOWNSTREAM SLUICE GATES

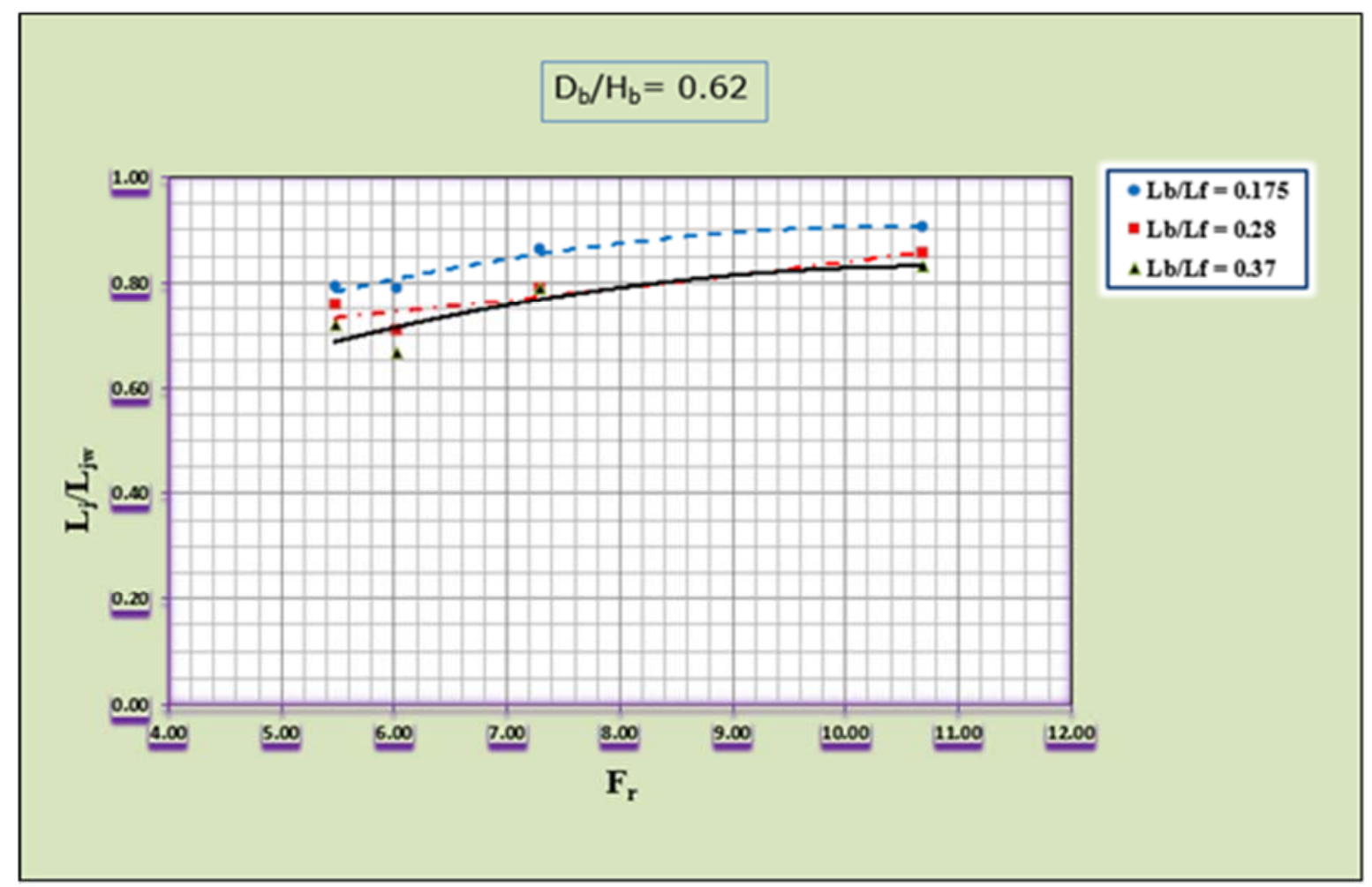

Figure (7) Relation between $\left(\mathrm{F}_{\mathrm{r}}\right)$ and $\mathrm{L}_{\mathrm{j}} / \mathrm{L}_{\mathrm{jw}}$ for $\mathrm{D}_{\mathrm{b}} / \mathrm{H}_{\mathrm{b}}=0.62$

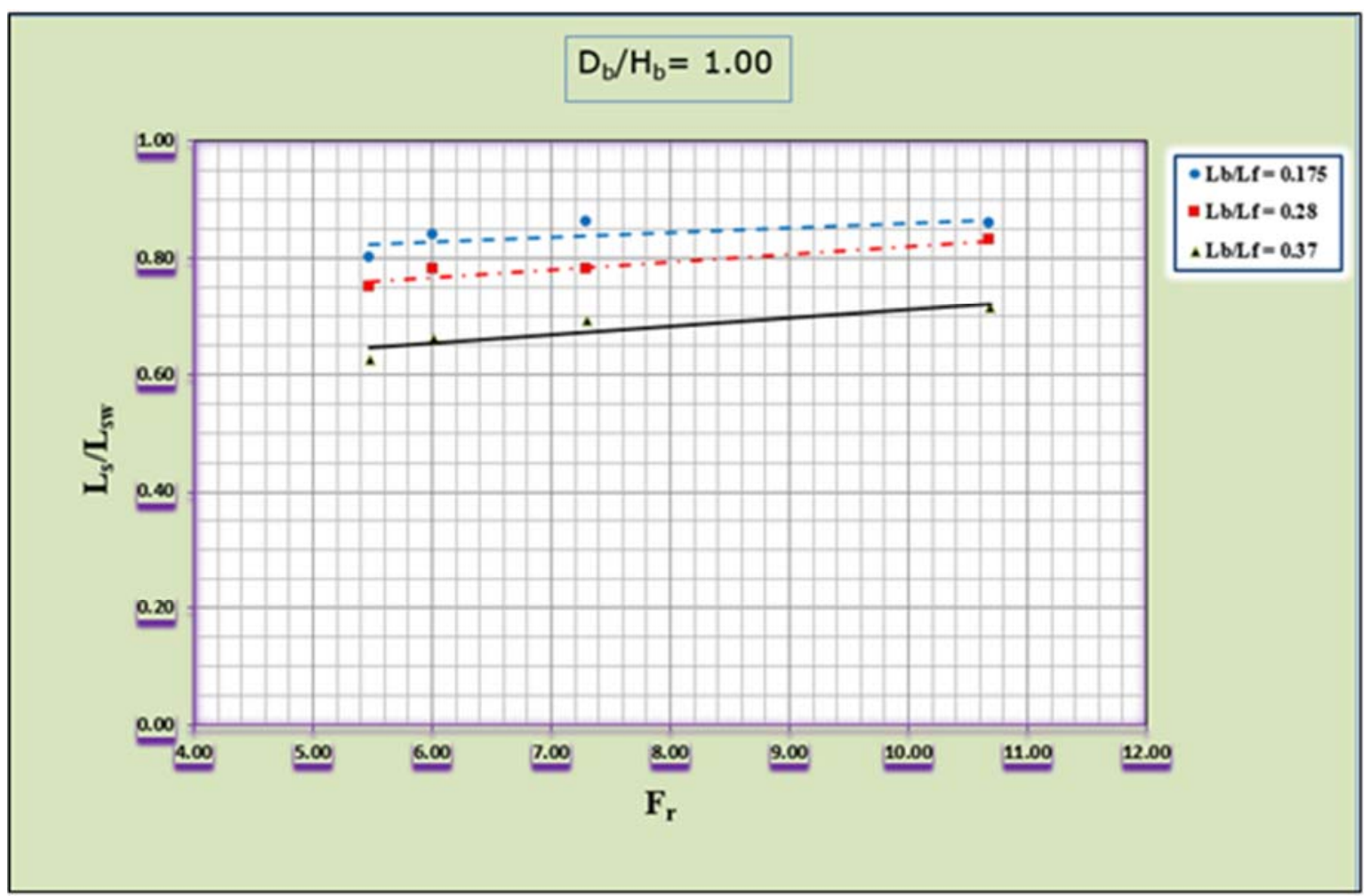

Figure (8) Relation between $\left(\mathrm{F}_{\mathrm{r}}\right)$ and $\mathrm{L}_{\mathrm{s}} / \mathrm{L}_{\mathrm{sw}}$ for $\mathrm{D}_{\mathrm{b}} / \mathrm{H}_{\mathrm{b}}=1.00$ 
ASSESSING THE IMPACT OF SEMI-CIRCULAR BAFFLE BLOCKS ON SCOUR DOWNSTREAM SLUICE GATES

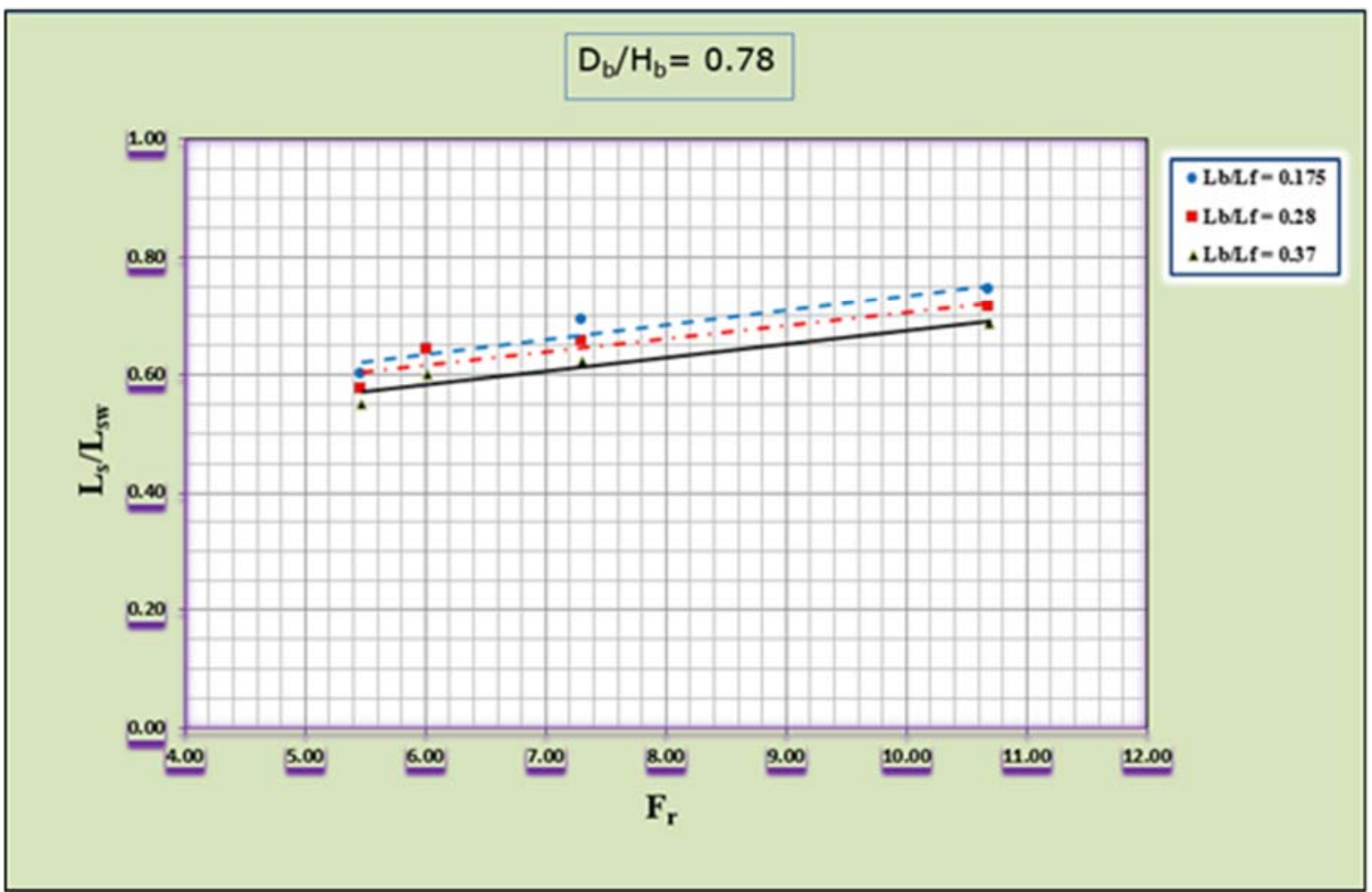

Figure (9) Relation between $\left(\mathrm{F}_{\mathrm{r}}\right)$ and $\mathrm{Ls} / \mathrm{L}_{\mathrm{sw}}$ for $\mathrm{D}_{\mathrm{b}} / \mathrm{H}_{\mathrm{b}}=0.78$

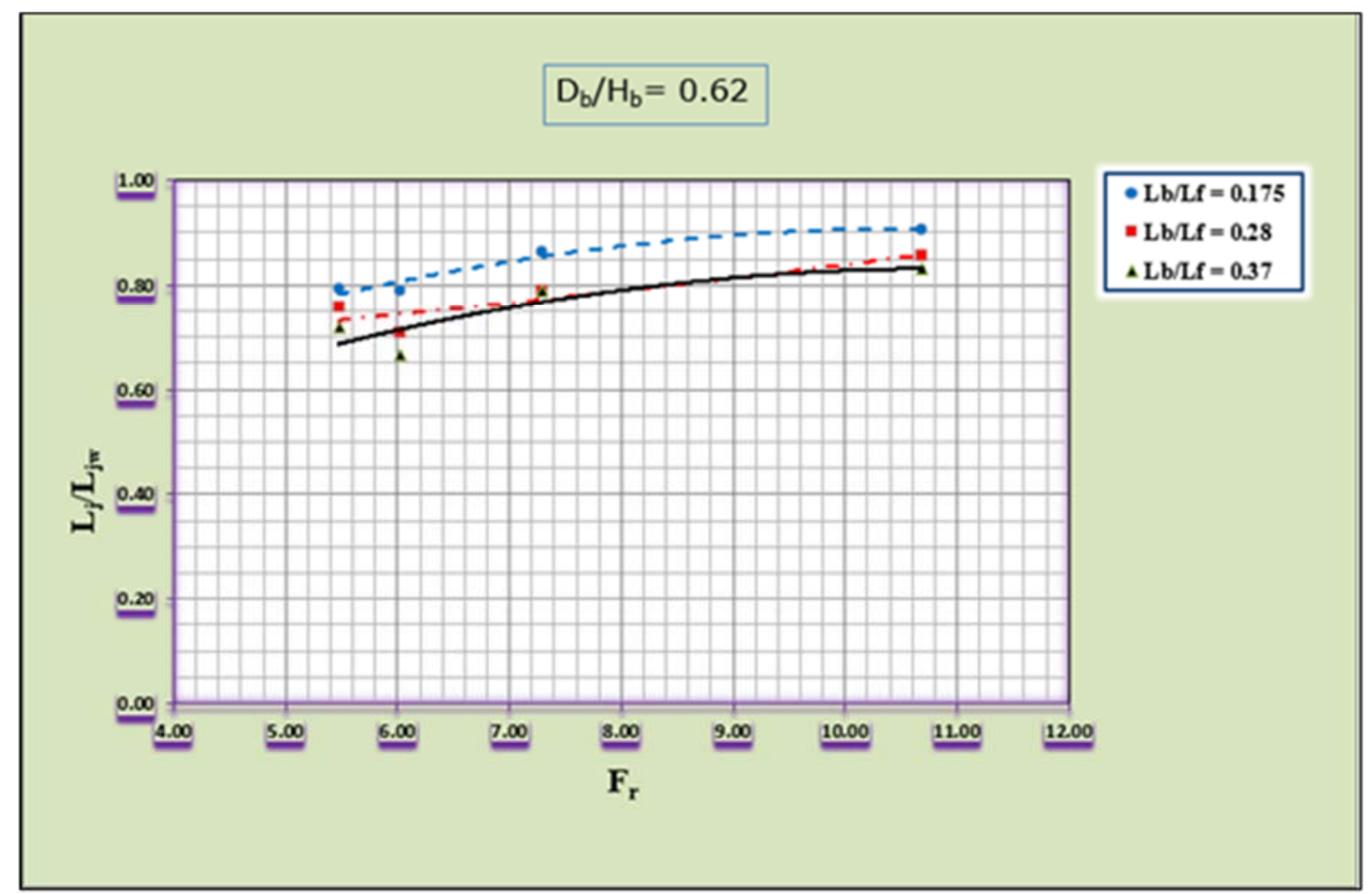

Figure (10) Relation between $\left(F_{r}\right)$ and $L_{s} / L_{s w}$ for $D_{b} / H_{b}=0.62$ 
ASSESSING THE IMPACT OF SEMI-CIRCULAR BAFFLE BLOCKS ON SCOUR DOWNSTREAM SLUICE GATES

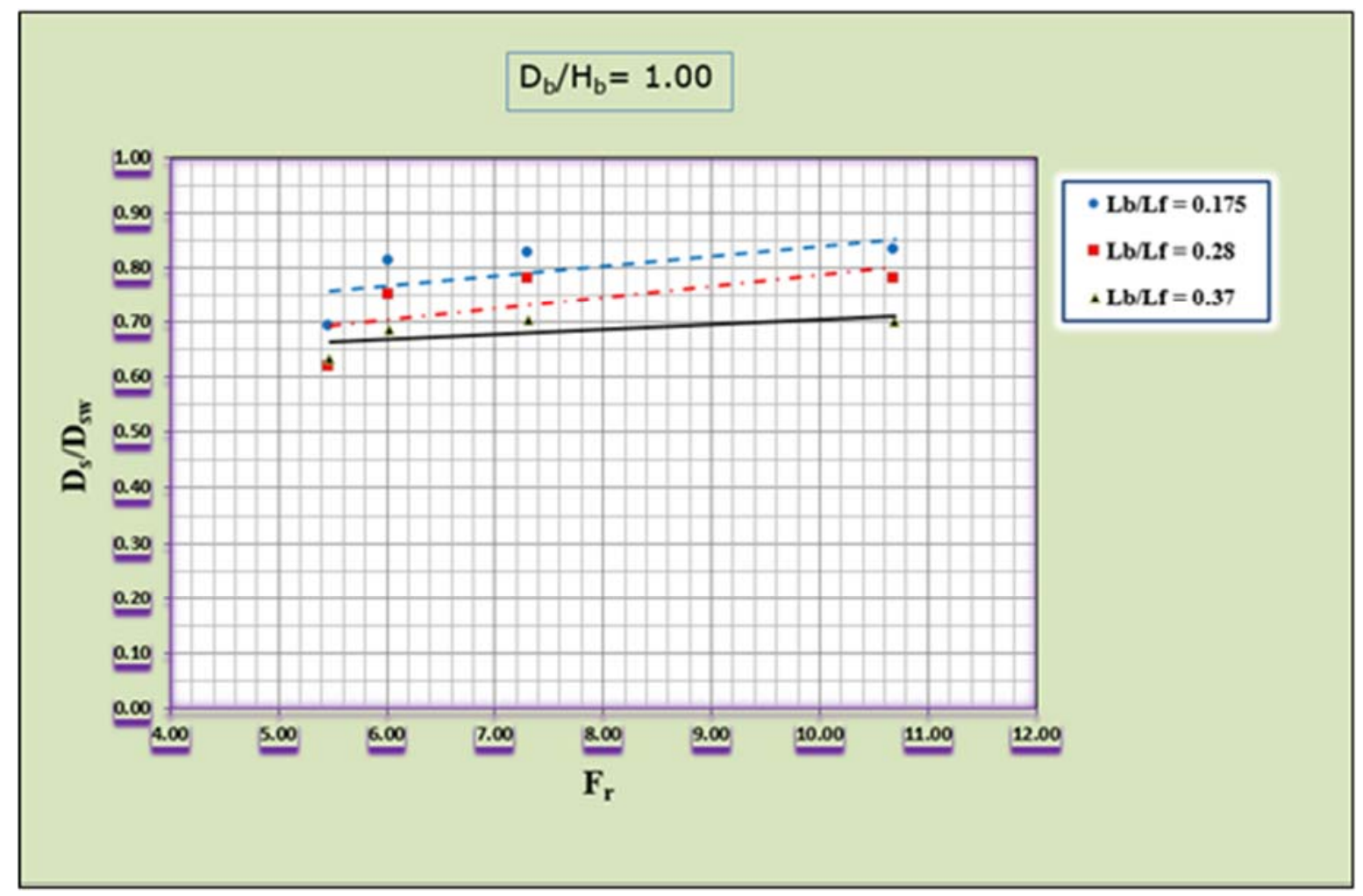

Figure (11) Relation between $\left(\mathrm{D}_{\mathrm{s}} / \mathrm{D}_{\mathrm{sw}}\right)$ and $\left(\mathrm{F}_{\mathrm{r}}\right)$ for $\mathrm{D}_{\mathrm{b}} / \mathrm{H}_{\mathrm{b}}=1.00$

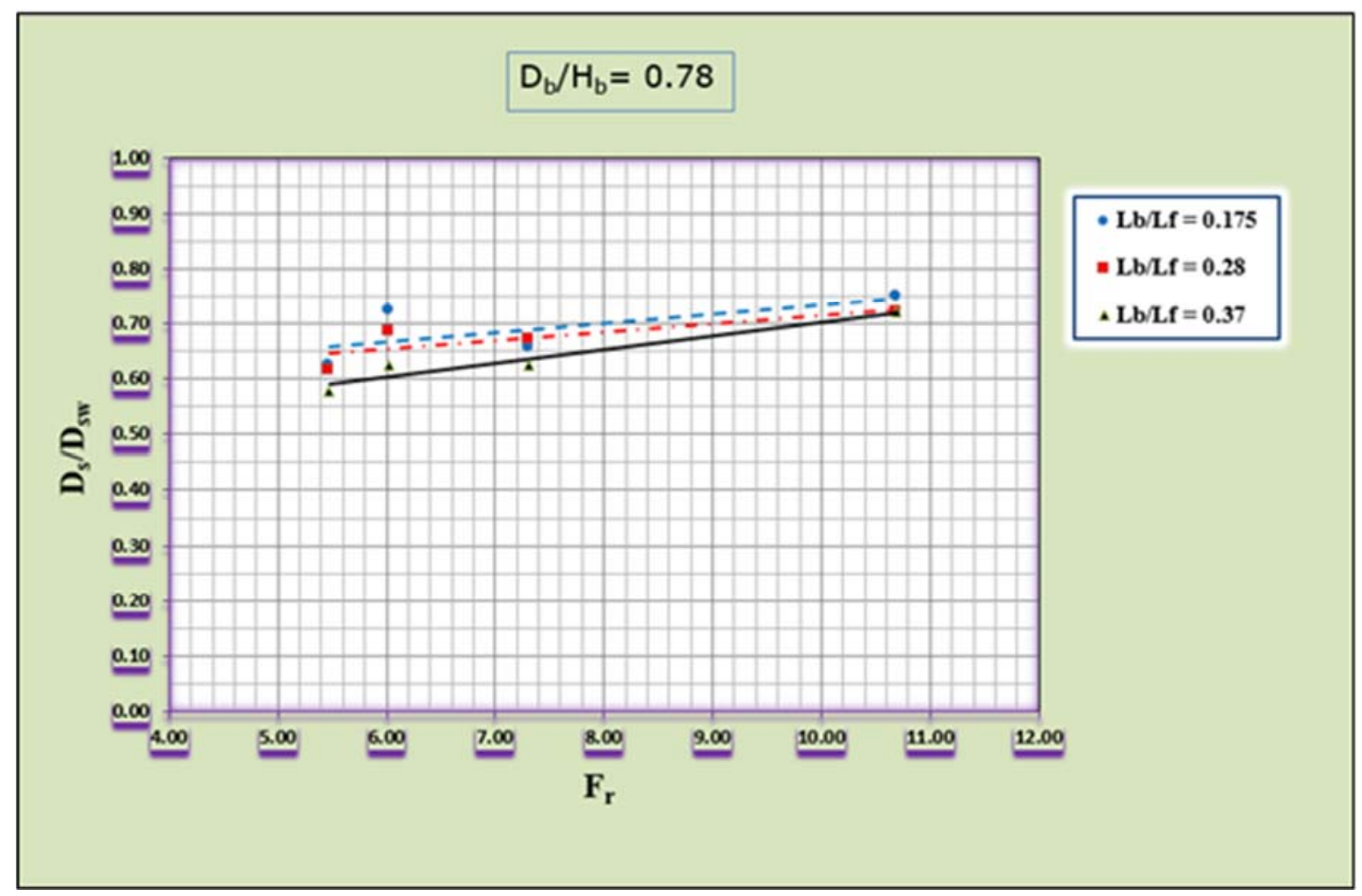

Figure (12) Relation between $\left(\mathrm{D}_{\mathrm{s}} / \mathrm{D}_{\mathrm{sw}}\right)$ and $\left(\mathrm{F}_{\mathrm{r}}\right)$ for $\mathrm{D}_{\mathrm{b}} / \mathrm{H}_{\mathrm{b}}=0.78$ 


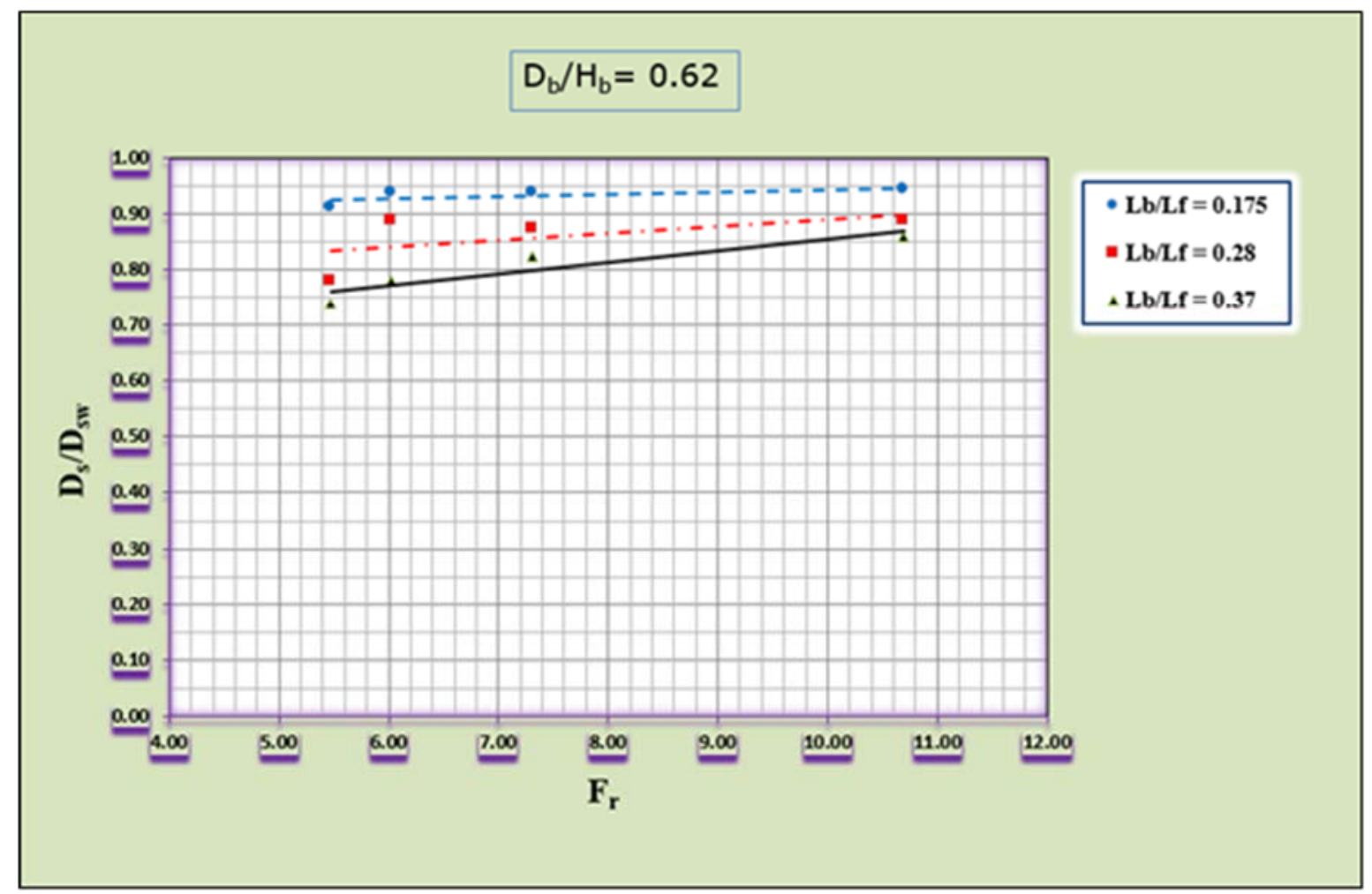

Figure (13) Relation between $\left(\mathrm{D}_{\mathrm{s}} / \mathrm{D}_{\mathrm{sw}}\right)$ and $\left(\mathrm{F}_{\mathrm{r}}\right)$ for $\mathrm{D}_{\mathrm{b}} / \mathrm{H}_{\mathrm{b}}=0.62$ 